Галаган В. I., к.військ.н., доцент, (ORCID: 0000-0001-9578-0895);

Полішко С. В. к.т.н., с.н.с., $\quad$ (ORCID: 0000-0002-2172-7618);

Бондарчук С. В.,

(ORCID: 0000-0003-0624-9782)

Центр воєнно-стратегічних досліджень Національного університету оборони України імені Івана Черняховського, Київ

\title{
Пропозиції щодо формування структури інформаційно- аналітичного автоматизованого робочого місця керівного складу за напрямом управління нерухомим військовим майном Збройних Сил України
}

Резюме. Стаття присвячена питанням обгрунтування пропозицій щодо формування структури інформаційно-аналітичного автоматизованого робочого місця керівного складу за напрямом управління нерухомим військовим майном Збройних Сил України.

Ключові слова: інформаційно-аналітичне автоматизоване робоче місце; автоматизоване робоче місце керівного складу; управління нерухомим військовим майном.

Постановка проблеми. Збройні Сили України на сьогодні знаходяться на етапі проведення оборонної реформи. Одним із найактуальніших завдань під час оборонної реформи $\epsilon$ створення та впровадження інформаційних систем управління.

У рамках Плану дій щодо впровадження оборонної реформи у Міністерстві оборони та Збройних Силах України у 2016 - 2020 роках і Концепції інформатизації Міністерства оборони України заплановане створення інформаційної системи управління оборонними ресурсами Defence Resource Management Information System (DRMIS).

Дані, що використовують системи оборонного планування спрямовані на проведення оцінювання забезпеченості всіма видами ресурсів, ефективності їх використання, моделювання перспективних структур та інтеграції цих систем до системи інформаційної підтримки прийняття рішень $[1,2]$. Для ефективного використання великої кількості масивів даних командиру (начальнику) необхідно застосовувати засоби ïx обробки. Одним із найпоширеніших для використання є автоматизовані робочі місця (APM).

Особливо актуальним це питання є під час залучення частин і підрозділів ЗС України до виконання завдань операції об'єднаних сил (ix забезпечення ресурсами, розміщення, передислокація) потребують прийняття обгрунтованих рішень керівним складом за напрямом управління нерухомим військовим майном ЗС України.
На сьогодні здійснюється розроблення макету автоматизованого інформаційноаналітичного робочого місце керівного складу (IA APM), яке може стати одним 3 елементів системи підтримки прийняття рішень і певною мірою забезпечить етап інформаційної підготовки управлінського рішення.

Ступінь розробленості проблеми. Нині єдиною системою, яка прийнята в постійну експлуатацію $\epsilon$ підсистема управління нерухомим майном "Майно" - складова Єдиної системи управління адміністративногосподарчими процесами Збройних Сил України. Робота цієї підсистеми направлена на оптимізацію процесів планування, розподілу та використання ресурсів для забезпечення життедіяльності військ та отримання достовірної інформації, необхідної для прийняття управлінських рішень керівництвом ЗС України щодо управління нерухомим військовим майном. Система побудована на програмній платформі $S A P$ та має потужну інформаційну базу даних (типи, площі, об'єми, приналежність, статуси тощо), щодо об'єктів нерухомості, які знаходяться на балансі ЗС України. Але, вказана інформація та іiі вигляд більш затребувана посадовими особами, які займаються обліком, обслуговуванням та експлуатацією об'єктів нерухомості.

Водночас, керівний склад 3С України який безпосередньо здійснює управління нерухомим військовим майном не має повноцінного функціонального інформаційноаналітичного автоматизованого робочого місця, яке повною мірою задовольнить їх потреби під час прийняття обгрунтованих рішень. Отже 
розроблення макету IA APM $\epsilon$ одним із першочергових завдань у сфері управління нерухомістю, яке висувається керівним складом Міністерства оборони України.

Зважаючи на вищевикладене, метою статті $\epsilon$ обгрунтування пропозицій щодо формування структури інформаційноаналітичного автоматизованого робочого місця керівного складу за напрямом управління нерухомим військовим майном Збройних Сил України.

Виклад основного матеріалу. Традиційна інформаційно-телекомунікаційна інфраструктура, яка створена в ЗС України, не може повністю задовольняти потреби одночасно транзакційних i аналітичних систем, які розробляються та вже впроваджених. Це призводить до того, що в архітектурі систем вносяться додаткові зміни.

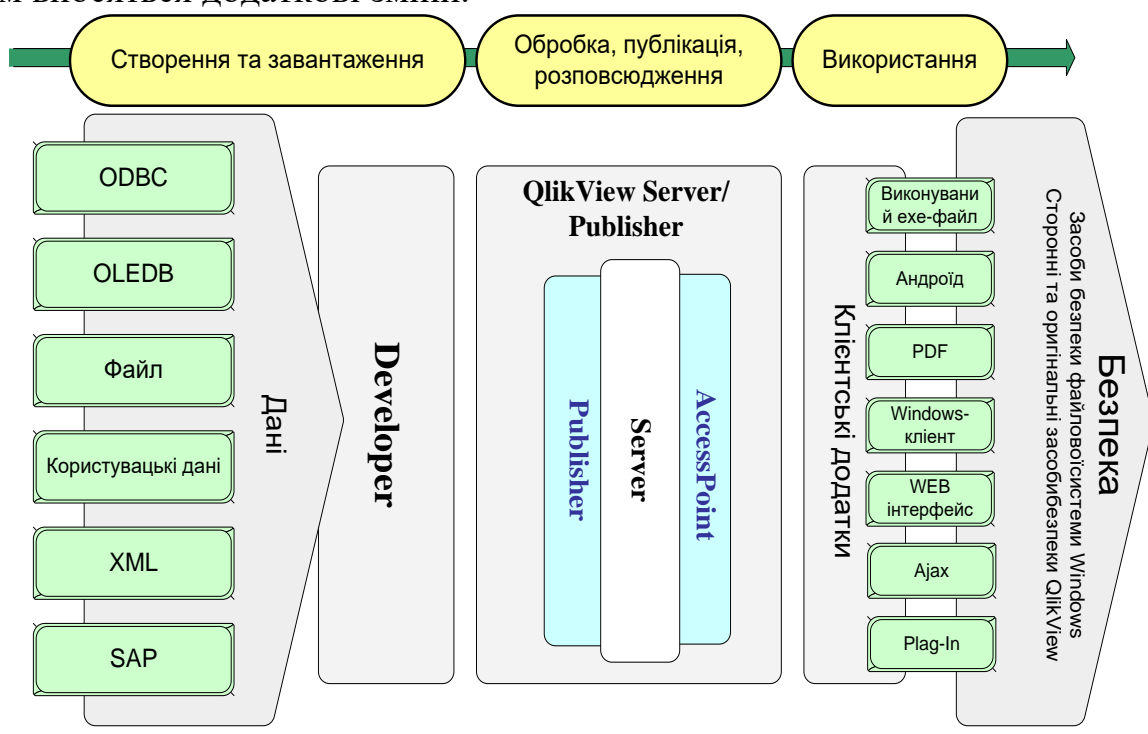

Рис. 1. Функціональна схема QlikView
Робота макету IA APM зводиться до виконання таких $\boldsymbol{n}$ 'яти етапів:

Завантаження вхідних даних $i$ створення моделі даних. Макет здатний добувати і об'єднувати дані 3 безлічі різнорідних джерел, не використовуючи в явній формі додатки імпорту або експорту даних із зовнішніх систем. Як результат користувач може централізовано аналізувати дані незважаючи на їх походження i отримувати цілісне уявлення про діяльність підрозділів (структур) ГоловКЕУ ЗС України та процеси управління об'єктами нерухомості.

Для макету IA APM основним джерелом $\epsilon$ стандартні формати файлів (Microsoft Excel, текстові файли).

Створення додатку проводиться налаштуванням відповідних елементів екранів і прив'язки їх до моделі даних, за допомогою
Як було визначено у попередніх напрацюваннях [3,4], IA APM має бути складовою певної інформаційно-аналітичної системи. 3 огляду на наявні системи обліку нерухомого військового майна у ЗС України та наявного інструментарію бізнес-аналізу (аналітичні системи, які є у користуванні 3С України), для експериментального макетування було вирішено використати сучасну систему бізнес-аналізу (Business Discovery) на базі програмного забезпечення QlikView. Це програмне забезпечення дає змогу зменшити складність і вартість, пов'язану з поділом на транзакційну і аналітичну частину шляхом їx об'єднання. QlikView складається 3 певних програмних компонентів додатку і будується 3 урахуванням функціональної схеми (рис. 1). математичних i статистичних функцій. Для виконання цих завдань використовується компонент Developer (середовище розробки та візуалізації), яке дає змогу створювати скрипт завантаження і візуальні представлення даних для додатків.

У скрипті завантаження визначено джерело даних і вказується, які саме дані з них вилучатимуться та порядок їх обробки.

Наступним кроком $\epsilon$ візуалізація, яка робить числові дані нагляднішими. Система має вбудований гнучкий, інтуїтивно зрозумілий i розвинений механізм візуалізації даних.

Після отримання даних і перетворення їх у необхідний вид за допомогою Developer створюється інтерактивні візуальні уявлення, які допоможуть користувачам відповісти на актуальні управлінські питання щодо об'єктів нерухомості (рис. 2). 


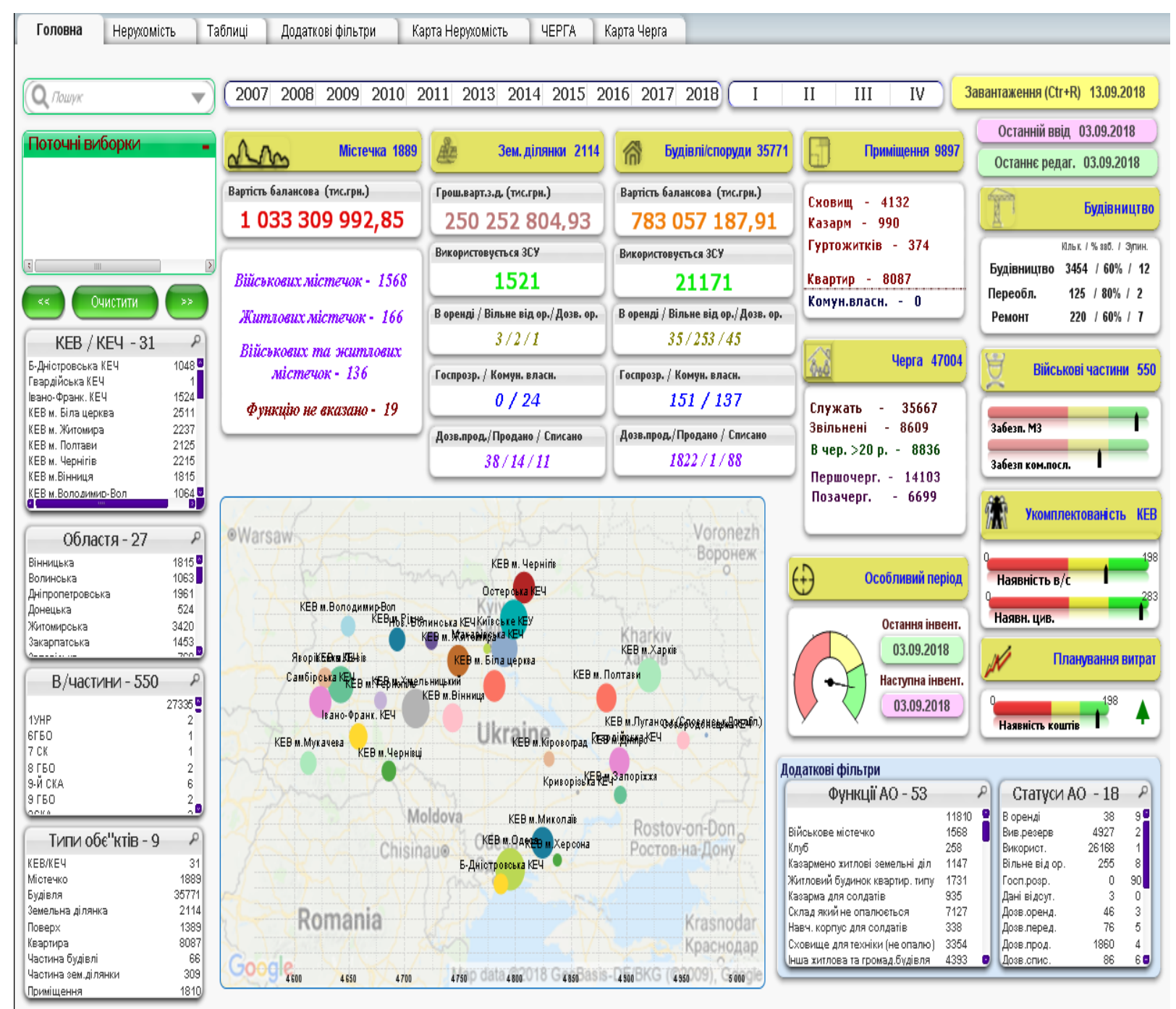

Рис. 2. Екран візуалізації обліку нерухомого майна

Перезавантаження, публікаиія та доставка контенту. QlikView Server i його підсистеми виконують завдання перезавантаження, захисту, управління контентом i його доставки кінцевим користувачам. До того ж користувачі звертаються до сервера, на якому зберігається контент (інформаційне наповнення IA APM). Server відповідає за організацію клієнтсерверного доступу до програм i даних, зберігає документи i робить їх доступними кінцевим користувачам. За необхідності допомагає планувати операції перезавантаження даних, проте, зазвичай за планування відповідає модуль Publisher.

Publisher реалізує додаткові функції планування i доставки. Додатковий (опціональний) компонент Publisher призначений для створення складних сценаріїв розповсюдження контенту, типових для великих організацій (структур). Він розширюе i поліпшує функціональні можливості Server в області адміністрування i забезпечує додатковий захист контенту на рівні користувачів і груп.

AccessPoint - точка доступу, яку можна налаштувати до всіх програм QlikView. За ii допомогою користувачі звертаються до всіх програм відповідно до прав доступу. Крім того, Access Point підтримує різні фонові сервіси, наприклад, розподіл i балансування навантаження між декількома серверами QlikView, об'єднаними в кластер.

Доступ до данних з будь-якого місия (за наявності мережі ITM “Дніпро”). IA АРM готове до використання одразу після надання доступу до даних і додатків, виконаного за допомогою Server. Водночас виконується головний принцип - дані та додатки QlikView мають бути доступні користувачу в будь-який час і будь-якому місці (за наявності мережі ITM “Дніпро").

За допомогою доступних браузерів доступ до даних можливий з будь-якого ПК або ноутбука. QlikView підтримує два типи браузерних клієнтів: додатковий модуль для Microsoft Internet Explorer i Ајах-клієнт 
(останній не потребує попередньої інсталяції). Можливе використання мобільних пристроїв, що надасть додаткові зручності користувачам.

Спеціальний користувач (клієнт) із встановленим програмним забезпеченням уможливлює онлайн-доступ і внесення змін. Документи QlikView самодостатні, тому у випадках, коли доступ до сервера неможливий, дані можна аналізувати локально за допомогою встановленої на ПК клієнтської програми.

Також, є можливість отримання звітів електронною поштою. Якщо для прийняття рішень командиру (начальнику) досить звичайних звітів, їх можна отримувати від підлеглих електронною поштою в форматі PDF. За доставку таких документів відповідає модуль Publisher.

Файл qlikview містить все необхідне для проведення аналізу. Файл, створений у форматі QlikView (документ QlikView), відрізняється самодостатністю, простотою у використанні та можливістю бути перенесеним.

Документи QlikView містять такі скрипт завантаження, який добуває i обробляє вихідні неагреговані дані;

визначення, необхідні для наочного подання даних в інтерфейсах IA APM;

описи діаграм, графіків й інших візуальних елементів інформаційних панелей i звітів щодо об'єктів нерухомості;

дані, які підлягають аналізу.

У документах QlikView можуть перебувати дані, які підлягають аналізу; вони представлені в стислому вигляді 3 високим ступенем компресії. Це дає змогу виконувати аналіз як в режимі офлайн, так і в клієнтсерверному варіанті, завантажуючи дані в оперативну пам'ять за необхідністю.

Після публікації (викладення) документа QlikView на сервері його вміст стає доступним для всіх користувачів IA APM (з урахуванням їх повноважень).

3 огляду на зазначене, структурну схему експериментального макету IA АРМ керівного складу за напрямом управління нерухомим військовим майном 3С України наведено на рис. 3. компоненти:

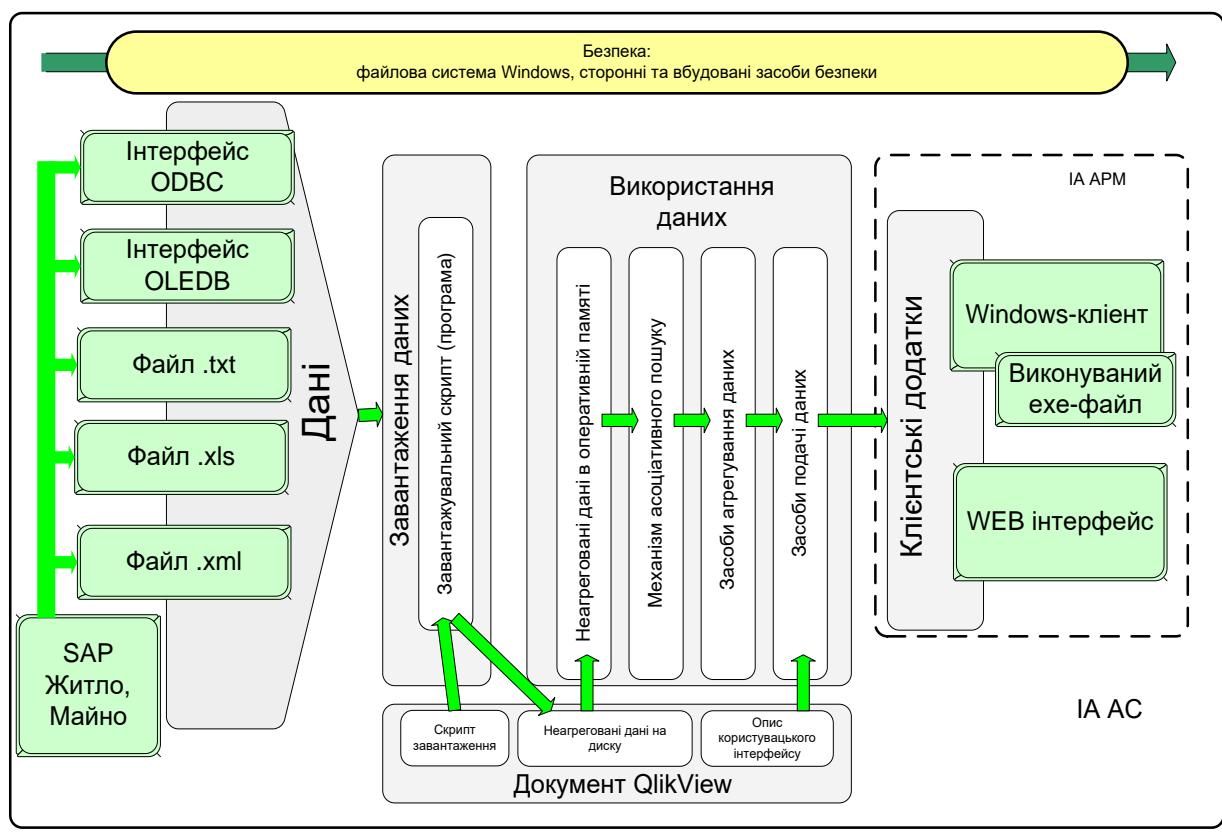

Рис. 3. Структурна схема експериментального макету

Для детального аналізу структури макету, що створюється, необхідно розглянути підходи до архітектури установки i розгортання програмного забезпечення QlikView. На рис. 4 наведено схему розгортання QlikView та місце розташування компонентів QlikView.

Зовнішній інтерфейс (front end) - місце, де користувачі взаємодіють 3 документами $\mathrm{i}$ даними, які їм дозволено переглядати через сервер. Ці документи, зазвичай створюються через Publisher у внутрішньому інтерфейсі (back end) і відбувається взаємозв'язок між клієнтом і сервером, сервер відповідає за авторизацію користувача. Зовнішній інтерфейс використовує ресурси інфраструктури. Аутентифікація користувачів здійснюється за межами QlikView. 


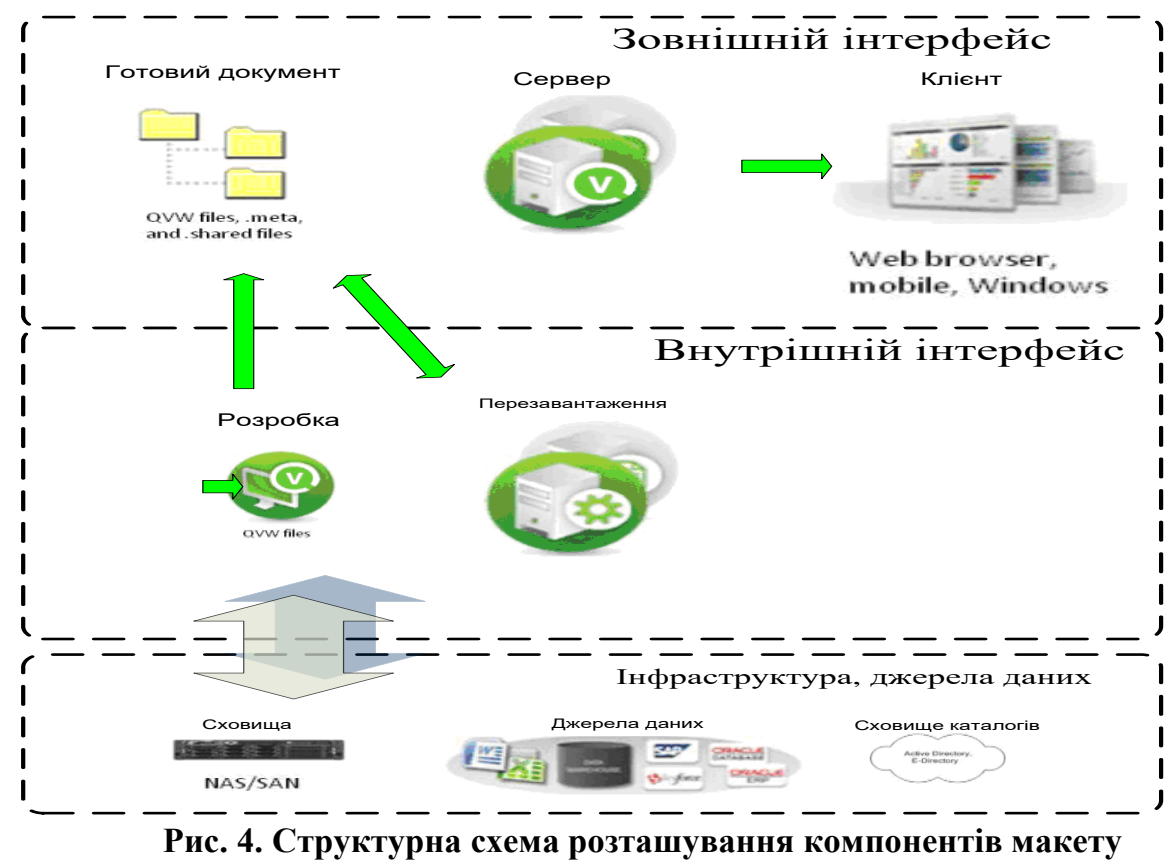

У внутрішньому інтерфейсі (back end) знаходяться вихідні документи, створені за допомогою Developer (середовища розробки). Дані файли містять сценарії отримання даних 3 різних джерел даних, наприклад, сховища даних, файли Microsoft Excel®, CRM, ERP, АБС.

Проте у внутрішньому інтерфейсі розміщуються проміжні файли (файли QVD). Основним компонентом QlikView, який виконує завантаження i поширення $\mathrm{y}$ внутрішньому інтерфейсі, $\epsilon$ сервіс поширення (Distribution Service). У середині сервера файлова система Windows відповідає за авторизацію (тобто, QlikView не несе відповідальності за будь-які права доступу).

Серверна частина використовує ресурси інфраструктури для кластеризації (наприклад, загальний ресурс Windows) та може використовувати такі ресурси, як SMTP (поштові) - сервери і каталоги.

Таким чином, можна дійти висновку, що зовнішній i внутрішній інтерфейси

можливо використовувати не тільки для розроблення макету, але i для розроблення, тестування та розгортання повноцінного IA APM.

На сьогодні для створення макету IA APM використано програмне забезпечення QlikView без Publisher. Без складової Publisher архітектура QlikView стає обмеженішою. Усі засоби поширення і спільної роботи видаляються і замінюються перезавантаженням безпосередньо в призначених для користувача документах. У цьому випадку необхідно вручну розмістити файл .qvw на сервері. Але, для проведення макетування це обмеження не $є$ суттевим.

Архітектура комунікації сервера QlikView Server i клієнта (рис. 5) потребує наявності трьох основних процесів, які мають бути здатні взаємодіяти один 3 одним послідовним i безпечним способом. Ця взаємодія може потенційно включати кілька машин і кілька мережевих підключень й інші підпорядковані процеси

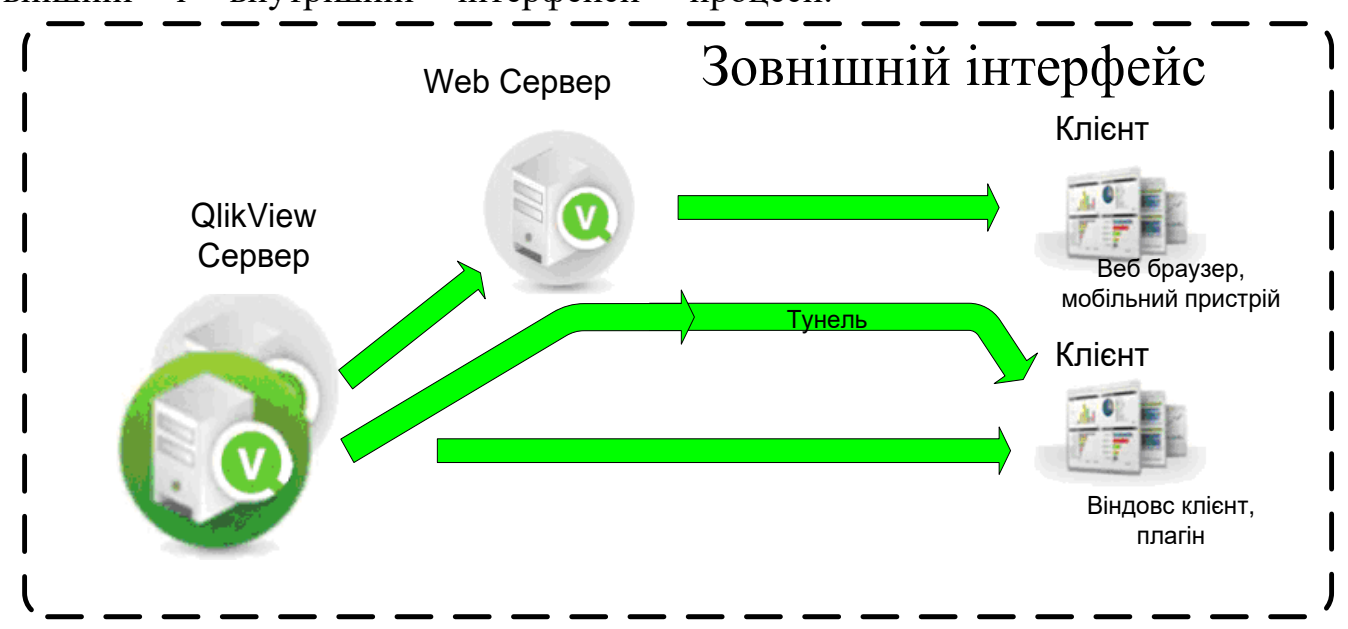

Рис. 5 Архітектура комунікації компонентів сервера QlikView. 
Нижче описані основні компоненти сервера QlikView (табл. 1) і процеси, які вони виконують (табл. 2).

Аутентифікація користувачів-клієнтів виконується поза QlikView з використанням зовнішньої системи, наприклад, перевірки автентичності Windows.

Нижче перераховані протоколи, які використовуються системою для взаємодії клієнта 3 QVS.

\begin{tabular}{|l|l|}
\hline Компонент & \multicolumn{1}{|c|}{ Опис } \\
\hline $\begin{array}{l}\text { QVS } \\
\text { QlikView } \\
\text { Server) }\end{array}$ & $\begin{array}{l}\text { Делегує клієнту, на якому встановлена операційна система Microsoft Windows, відповідно до } \\
\text { повноважень функції QlikView. }\end{array}$ \\
\hline Kлієнт & $\begin{array}{l}\text { Запускається у веб-браузері або оболонці додатку, який формує контейнер для клієнтського коду. } \\
\text { Клієнт взаємодіє 3 QVS або безпосередньо, або через веб-сервер, щоб забезпечити інтерфейс і } \\
\text { функціональність для кінцевого користувача. }\end{array}$ \\
\hline Web server & $\begin{array}{l}\text { Запускає htтр-сервер, який може використовуватися для доставки веб-сторінок html клієнту, } \\
\text { допомагає з аутентифікацією користувача і забезпечує зв'язок між клієнтом і QVS. }\end{array}$ \\
\hline
\end{tabular}

\begin{tabular}{|l|l|}
\multicolumn{1}{|c|}{ Протокол } & \multicolumn{1}{|c|}{ Оаблиця 2} \\
\hline $\begin{array}{l}\text { QVP } \\
\text { (QlikView Protocol) }\end{array}$ & $\begin{array}{l}\text { Зашифровані, бінарні і засновані на протоколі TCP; Безпосередньо } \\
\text { пов'язується 3 QVS портом 4747. }\end{array}$ \\
\hline QVPX & $\begin{array}{l}\text { На основі формату XML; спілкується 3 QVS, використовуючи http / https } \\
\text { через веб-сервер. }\end{array}$ \\
\hline
\end{tabular}

$\begin{array}{clll}\text { Під час } & \text { створення макету } & \text { Microsoft IIS, щоб можна було встановити } \\ \text { використовується } & \text { Клієнт Windows } \mathrm{i} & \text { тунельний зв'язок. }\end{array}$

Клієнт АJАX.

Кліснти Windows (.exe/.ocx)

обмінюються даними безпосередньо 3 QVS, використовуючи QVP на порту 4747. Ці клієнти не потребують, щоб веб-сервер встановлював і підтримував зв'язок з QVS.

Клієнти AJAX і мобільні клієнти не обмінюються даними безпосередньо 3 QVS. Вони встановлюють і підтримують з'єднання з використанням протоколу QVPX через вебсервер (QVWS) або Microsoft IIS.

Для роботи користувача 3 документами, необхідно, щоб виконувалися такі умови:

для користувача існує ліцензія Client Access License (CAL);

у користувача $є$ доступ до документа.

Документи користувача завжди зчитуються за допомогою QVS. Права доступу зберігаються або в списку ACL документа (коли QVS працює в режимі NTFS), або у файлі META (коли QVS запускається в службі метаданих документа, тобто в режимі DMS). Ці настройки $\epsilon$ частиною дистрибутива внутрішнього інтерфейсу (Back End).

Тунель (Tunnel). Якщо комунікаційний порт QVS (4747) заблокований в мережевому брандмауері, клієнт Windows спробує перенаправити їх з'єднання через порт 80 (http). Цей шлях підключення має бути дозволений в QVWS або бути встановлений в
Конектор служби каталогів (DSC) відповідає за отримання призначеної для користувача інформації, пов'язаної з кінцевими користувачами, 3 різних джерел, включаючи (але не обмежується ними) Active Directory, LDAP, ODBC і призначених для користувача.

Макет інтерфейсу. Для аналізу процесів управління нерухомим військовим майно та для роботи 3 аналітично-асоціативною моделлю, яка розміщується в QVWS, необхідно розробити макет інтерфейсу. Макет інтерфейсу розроблено за методологією DAR. Додатки (файли QV), створені за цією методологією дають змогу користувачам отримувати доступ до сторінок у будь-якому порядку. Проте ієрархія подачі інформації збережена: від узагальнених даних на Dashboard (екрані 3 показниками ефективності), до деталей, наведених у таблицях звітності.

Dashboard відображає тільки найважливішу інформацію для розуміння повного стану управлінської діяльності командира (начальника) i $€$ найменш інтерактивною частиною аналітичного додатка. На екрані (рис. 6) відображаються ключові показники квартирно-експлуататаційного забезпечення. Тобто, Dashboard виконує функцію змісту функціональної діяльності командира (начальника), і $є$ відправною точкою 
для розуміння, що відбувається 3 процесами діяльності щодо об’єктів нерухомості.

Ключовими правилами під час побудови Dashboard IA APM були: виділення тільки загальної і високорівневої інформації; виділення найбільш пріоритетних показників; виведення на екран тільки основних фільтрів; створення візуальної ієрархії елементів, яка допоможе сприйняттю інформації (найважливіші дані мають бути більшого розміру, ніж менш важливі).

Aналіз (Analysis). Сторінки додатку які наводять дані аналізу, $є$ інтерактивнішими, i орієнтовані на повноцінне дослідження даних щодо об'єктів нерухомості. Кожна сторінка аналізу IA APM присвячена окремому напрямкові діяльності (функціональній області) структури (підрозділу), за якою проводиться аналіз. Між усіма сторінками додатку користувач може вільно переміщуватися із збереженням вибірки (встановленого фільтра). Збільшено кількість графіків і таблиць, ніж на екрані 3 показниками, що надає користувачеві набір інструментів для дослідження даних щодо об'єктів нерухомості.

У процесі побудови екранів аналітики були використані такі правила: використані додаткові фільтри та фільтри-списки; на сторінці розміщується тільки інформація за конкретним напрямом діяльності; застосовується вертикальна прокрутка сторінки; використовуються і графіки, i таблиці.

Звіти (Reporting). Екрани цього рівня пропонують детальнішу інформацію у вигляді таблиць. Для прийняття обгрунтованого управлінського рішення користувач має проводить на сторінках Analysis i Reporting найбільше часу.

Під час розроблення IA АPM використані такі правила розроблення звітів:

надана максимально детальна інформація для користувача щодо об'єктів нерухомості;

надані додаткові дані, що можуть знадобитися для остаточного ухвалення рішення.

У зв'язку 3 тим, що IA APM використовує велику кількість вимірів об'єктів нерухомості (типи, площі, об'єми, відповідальні, приналежність, статуси тощо) за якими проводиться фільтрація створені окремі сторінки 3 фільтрами для зручної вибірки.

У цілому вибрана та реалізована методологія для створення макету (на основі триступеневої моделі створення візуального додатку) дає змогу ефективно працювати 3 інформацією за об'єктами нерухомості в програмному продукті QlikView i підходить для різних рівнів органів управління [5].

Така реалізація інтерфейсів (екранів) дає змогу керівникові бути компетентним, володіти дійсною ситуацією щодо нерухомого військового майна, адекватно оцінювати його стан, робити правильні висновки та приймати обгрунтовані рішення.

Для опробування макету була проведена його попередня презентація керівному складу ГоловКЕУ ЗС України, де були продемонстровані можливості запропонованого інструментарію. Для демонстрації макету були використані тестові дані щодо обліку нерухомого військового майна. За результатами проведеного показу, можна констатувати, що наявність у вищого керівництва ГоловКЕУ та 3С України таких зручних даних та звітів $€$ вагомим підгрунтям для прийняття раціональних рішень щодо управління нерухомим військовим майном.

Висновки. Таким чином, обгрунтовані пропозиції щодо формування структури інформаційно-аналітичного автоматизованого робочого місця керівного складу за напрямом управління нерухомим військовим майном Збройних Сил України дадуть змогу спростити розробку макету та прототипу IA APM, що значно зменшить витрати та часові показники.

Проведена практична демонстрація макету підтвердила можливості та необхідність використання IA APM, яке планується до експлуатації в майбутньому i надає повну видимість стану, функціонування об'єктів нерухомості для підготовки та прийняття обгрунтованих рішень командиром (начальником). Також визначено, що структура IA АРМ будується відповідності до інформації та даних 3 підсистеми управління нерухомим військовим майном "Майно", які використовуються в єдиній базі даних (циркулюють в мережі) на всіх рівнях (найвищому, середньому і нижчому), а також інформація 3 інших систем управління оборонними ресурсами.

Подальші дослідження за цією тематикою доцільно зосередити на детальному вивченні шляхів розв'язання проблем науковотехнічного супроводження розробки, впровадження та експлуатації АРМ керівного складу 3С України.

\section{СПИСОК ВИКОРИСТАНОЇ ЛІТЕРАТУРИ}

1. Закон України „Про організацію оборонного
планування“ / Відомості Верховної ради України - 
Офіц. вид. - К., 2005. - 97с. - (Бібліотека офіційних видань).

2. Стратегічний оборонний бюлетень України на період до 2015 року. / Міністерство оборони України. - К., 2004. - 64c. - (Бібліотека офіційних видань).

3. Галаган В. І., Бондарчук С. В. Полішко С. В. Застосування систем підтримки прийняття рішень в управлінні нерухомим військовим майном Збройних Сил України - К: ЗНП ЦВСД НУОУ, випуск № 2(63), 2018.

4. Галаган В. I., Бондарчук С. В. Полішко С. В. Формування загального обрису інформаційно- аналітичного автоматизованого робочого місця керівного складу управління нерухомим військовим майном Збройних Сил України - К: ЗНП ЦВСД НУОУ, випуск № 3(64), 2018.

5. Бондарчук С. В., Галаган В. I. Автоматизоване інформаційно-аналітичне робоче місце керівного складу 3С України за напрямком управління нерухомим військовим майном. Пропозиції щодо функціональності, загального обрису та технології створення. - К: ЦВСД НУОУ, Збірник матеріалів науково-практичного семінару “Актуальні питання управління проектами інформатизації в сфері безпеки і оборони”, тези. - 2018.

Стаття надійшла до редакційної колегії 06.11.2018

Галаган В. И., к.воен.н., доцент;

Полишко С. В., к.т.н., с.н.с.;

Бондарчук С. В.

Центр военно-стратегических исследований Национального университета обороны Украины имени Ивана Черняховского, Киев

Предложения по формированию структуры информационно-аналитического автоматизированного рабочего места руководящего состава по направлению управления недвижимым военным имуществом Вооруженных Сил Украины

Резюме. Статья посвящена вопросам обоснования предложений по формированию структуры информационно-аналитического автоматизированного рабочего места руководящего состава по направлению управления недвижимым военным имуществом Вооруженных Сил Украины.

Ключевые слова: информационно-аналитическое автоматизированное рабочее место; автоматизированное рабочее место руководящего состава; управления недвижимым военным имуществом.

V. Galagan, PhD (Military), assistant professor;

S. Polishko, PhD (Technical), senior researcher;

S. Bondarchuk

Center for Military and Strategic Studies National Defence University of Ukraine named after Ivan Chernyhovsky, Kyiv

Proposals for the formation of the structure of the informational-analytical automated workplace of the governing staff in the direction of management of the immovable military property of the Armed Forces of Ukraine

Resume. The article is devoted to questions of substantiation of proposals on formation of the structure of the informational-analytical automated workplace of the governing staff in the direction of management of the real property of the Armed Forces of Ukraine.

Keywords: an informational-analytical automated workplace; an automated workplace of the governing staff; and the management of immovable military property. 